\title{
Kendhangan Pamijen Gending Gaya Yogyakarta
}

\author{
Bambang Sri Atmojo ${ }^{1}$ \\ Jurusan Karawitan, Fakultas Seni Pertunjukan, Institut Seni Indonesia Yogyakarta
}

\begin{abstract}
ABSTRACK
Kendangan Pamijen of Yogyakarta Gamelan Performance. Kendhangan gaya Yogyakarta dibedakan menjadi tiga yaitu: (1) kendhangan dengan kendang setunggal kendang ageng antara lain kendhangan Pengrawit, Mawur, Mawur Tungkakan, Semang, Jangga, Candra, Sarayuda, Raraciblon, Bandholan, Majemuk, Lahela, Ladrang, Ketawang, Pinatut (Srepeg dan Ayak-ayak); (2) kendhangan dengan kendang kalih ( kendang ageng dan ketipung) antara lain kendhangan Gandrung-gandrung, Ladrang, Ladrang Gangsaran, Bimakurda, Sabrangan, Raja, Ketawang , Bubaran, Lancaran; dan (3) kendhangan dengan kendang batangan atau gembyakan antara lain kendhangan kebar, ciblon, playon, srepeg, sampak, dan kendhangan yang mengikuti gerak baik tari ataupun wayang. Beberapa kendhangan yang menggunakan kendang ageng, kendang kalih dan kendang batangan, ada yang memiliki bentuk dan garap yang sifatnya umum dan khusus atau pamijen. Kendhangan pamijen adalah kendhangan gawan gending, sehingga kendhangan ini merupakan kendhangan khusus untuk ngendhangi suatu gending bawaannya yang memiliki bentuk dan garap khusus. Kendhangan pamijen antara gending satu dengan yang lain ada yang sama bentuknya, tetapi berbeda sekaran-nya, bahkan ada yang bentuk dan sekaran-nya berbeda, perbedaan tersebut menjadi kekayaan bentuk dan garap serta merupakan ciri khas dari gending tertentu.
\end{abstract}

Kata kunci: Kendhangan, gamelan, pamijen, gending.

\section{Pendahuluan}

Kendang adalah salah satu ricikan atau instrumen dalam perangkat gamelan Jawa mempunyai peranan yang sangat penting. Hal ini dapat diketahui bahwa kendang selalu hadir dalam sajian uyon-uyon, iringan tari, iringan pakeliran dan iringan kethoprak dengan peran utamanya sebagai pamurba wirama, yaitu bertugas menguasai jalannya irama, menentukan tempo, serta memulai ataupun menghentikan penyajian. Dengan demikian kendang bertanggung jawab untuk mengatur nafas gending, sekaligus memberi kehidupan gending dalam karawitan. Selain itu kendang juga memberikan tekanan-tekanan sesuai gerak yang diiringi dengan permainan ritme untuk mempertegas ekspresi.

Di dalam tradisi karawitan gaya Yogyakarta, untuk mengetahui bentuk gending dapat dilihat atau didengarkan kendhangan-nya, maka dalam menyebutkan suatu gending selalu disertakan nama bentuk kendhangan-nya. Kendhangan gending gaya Yogyakarta ada yang sifatnya umum dan terdapat kendhangan gending khusus yang biasa disebut kendhangan pamijen (gawan gending). Kendhangan adalah pola permainan kendang, sedangkan pamijen dari kata dasar piji, yang mempunyai arti kang dipiji atau dipijekake (Poerwadarminta, 1939: 461). Kata pamijen mengandung pengertian sesuatu yang khusus atau dikhususkan. Gending dalam pengertian yang luas berarti komposisi gamelan, sedangkan pengertian yang sempit gending berarti komposisi gamelan dalam bentuk ageng dan tengahan yang terdiri dari dua bagian pokok. Bagian pertama lamba dan dados bersuasana tenang, agung. Bagian kedua dhawah biasanya bersuasana prenes, sigrak dan gumyak. Martopangrawit menyatakan bahwa gending pamijen adalah gending yang mempunyai garap khusus baik garapan irama maupun garapan ricikan tertentu, dan gending yang menyalahi hukum atau aturan bentuk gending yang telah ada

Gending pamijen dalam karawitan tradisi Yogyakarta pada dasarnya dapat dikelompokkan menjadi 2 bagian yaitu pamijen bentuk dan pamijen garap. Ciri dari pamijen bentuk adalah perubahan pada unsur-unsur bentuk gending yang meliputi jumlah gatra dan struktur permainan kelompok ricikan struktural (ketuk, kenong, kempul dan gong). Beberapa gending yang dapat dimasukkan dalam kelompok pamijen bentuk di antaranya gending Ganggong laras pelog patet nem kendhangan Ganggong, gending Longkrang

1 Alamat korespondensi: Prodi Karawitan ISI Yogyakarta, jalan Parangtritis KM 6,5 Sewon, Yogyakarta 55001. E-mail: bambangsa@isi.ac.id 
laras slendro patet sanga kendhangan Longkrang, gending Majemuk laras slendro patet manyura kendhangan Majemuk dan gending Loro-loro Topeng laras slendro patet manyura kendhangan Loro-loro. Adapun ciri dari pamijen garap adalah adanya spesifikasi garap yang terdapat dalam suatu gending. Spesifikasi garap tersebut dapat berupa pola permainan ricikan gender, rebab, kendang, bonang barung dan pola permainan irama serta laya. Beberapa gending yang dapat dimasukkan dalam kelompok pamijen garap antara lain gending Karawitan laras slendro patet nem kendhangan Candra, gending Jangkung Kuning laras pelog patet barang kendhangan Sarayuda Raraciblon, gending Dhegung Banten laras pelog patet lima kendhangan Semang, ladrang Janti laras slendro patet sanga, ladrang Teguhjiwa laras slendro patet sanga dan sebagainya. Untuk memahami pamijen garap suatu gending tidaklah mudah, karena diperlukan modal pengalaman garap yang cukup.

Dalam setiap penyajian karawitan baik yang berupa sajian uyon-uyon atau yang berfungsi sebagai iringan, kendhangan pamijen belum tentu semuanya disajikan. Dari sekian banyak kendhangan pamijen yang jarang disajikan apabila dibiarkan berlarut-larut dikhawatirkan akan kehilangan lacak, bahkan tidak menutup kemungkinan akan terjadi kepunahan. Untuk itu pada kesempatan ini penulis ingin mengkaji tentang kendhangan pamijen gending gaya Yogyakarta dalam suatu tulisan yakni bagaimana pola kendhangan pamijen dan bagaimanakah jika gending dengan kendhangan pamijen tidak digarap sebagaimana mestinya.

\section{Gending Gaya Yogyakarta}

Seni karawitan sebagai bentuk kesenian tradisional yang kita kenal dewasa ini ada beberapa gaya di antaranya gaya Bali, gaya Jawa Timur, gaya Jawa Tengah, gaya Jawa Barat. Bahkan ada spesifik gaya Banyuwangi, gaya Surabaya, gaya Cirebon, gaya Sunda, gaya Banyumas, gaya Surakarta, gaya Yogyakarta, masing-masing mempunyai corak dan karakter yang beraneka ragam. Menurut Poerwadarminta kata gaya berarti corak, ragam, irama dan lagu (untuk musik) (Poerwadarminta, 1989:258).

Berdasarkan pengertian tersebut kata gaya di dalam seni karawitan misalnya gaya Yogyakarta, berarti karawitan yang mempunyai corak, ragam, cara penyajian khas gaya Yogyakarta dan ciriciri khasnya tidak dimiliki oleh gaya karawitan lain baik mengenai garap tabuhan ricikan, pola penyajian maupun komposisi gendingnya.

\section{Pengertian Gending}

Salah satu unsur seni karawitan adalah gending, selain gamelan, pengrawit, wiraswara dan swarawati. Dalam buku Baoesastra Djawa, istilah gending berarti lelagoning gamelan (gending adalah lagu gamelan) (Poerwadaminta, 1939:143). Dalam buku Ensiklopedi Musik Indonesia Seri F-J, pengertian gending adalah komposisi lagu dalam musik gamelan sesuai dengan bentuk bangunnya (Ahmad Yunus, 1985:55). Martopangrawit dalam buku "Pengetahuan Karawitan I", disebutkan arti gending adalah lagu yang mempunyai bentuk tetapi keterangan ini khusus ditujukan pada gending yang menggunakan kethuk 2 kerep ke atas, sedangkan bentuk di bawahnya mempunyai nama tersendiri (Martopangrawit, 1975:7). Sejalan dengan pendapat tersebut di atas, Wulan Karahinan dalam buku yang berjudul "GendhingGendhing Mataraman Gaya Yogyakarta dan Cara Menabuh Jilid I", menyebutkan gending adalah bentuk gending-gending dengan klasifikasi ageng dan tengahan, sedangkan ladrang, ketawang, bubaran, lancaran disebut gending alit (Karahinan, 1991:12).

Dari beberapa pendapat di atas dapat disimpulkan bahwa gending dalam pengertian umum adalah komposisi lagu gamelan baik dalam bentuk ageng, tengahan maupun alit, sedangkan pengertian khusus gending berarti komposisi lagu gamelan dalam bentuk ageng dan tengahan. Gending ageng dan tengahan gaya Yogyakarta pada umumnya terdiri dari dua bagian pokok. Bagian pertama lamba dan dados bersuasana tenang, agung, sedangkan bagian kedua dhawah biasanya bersuasana lebih prenes, sigrak dan gumyak.

\section{Bentuk Gending}

Untuk mengetahui bentuk gending dalam tradisi karawitan Yogyakarta dapat dilihat atau didengarkan pada bentuk kendhangan-nya. Perlu diketahui bahwa penulisan gending-gending dalam beberapa naskah kuna (lama), penulisannya selain menyebutkan nama kendhangan juga mencantumkan jumlah tabuhan kethuk. Menurut penulis, sebenarnya penulisan gending dengan 
menyebutkan tabuhan kethuk dan kendhangannya lebih jelas dan lebih mudah dipahami terutama tabuhan kethuk yang digunakan pada suatu gending. Berdasarkan jumlah tabuhan kethuk dan bentuk kendhangan-nya, gending dapat dibedakan dalam tiga tingkatan sebagai berikut: (1) Gending ageng adalah gending dengan kethuk 8 arang dhawah kethuk 16 kendhangan Pengrawit atau Mawur Ageng, gending kethuk 8 kerep dhawah kethuk 16 kendhangan Semang Ageng, gending kethuk 4 arang dhawah kethuk 8 kendhangan Mawur, gending kethuk 4 kerep dhawah kethuk 8 kendhangan Semang untuk laras pelog dan kendhangan Jangga untuk laras slendro; (2) Gending tengahan adalah gending dengan kethuk 2 kerep dhawah kethuk 4 kendhangan Candra, Sarayuda, Majemuk, Gandrung-gandrung; (3) Gending alit yaitu gending-gending dengan kendhangan Ladrang, Ketawang, Bubaran, Lancaran. Di samping itu ada kelompok gending dengan kendhangan Patut atau Pinatut yaitu Ayak-ayak, Srepeg, Playon dan Sampak.

\section{Garap Penyajian Gending}

Gending gaya Yogyakarta dalam penyajiannya terdapat dua macam garap yaitu sajian soran dan lirihan. Soran berasal dari bahasa Jawa sero atau sora yang berarti keras (Poerwadarminta, 1939:579). Arti keras yang dimaksud adalah hasil bunyi tabuhan ricikan berpegang pada faktor keseimbangan dan rasa indah lagu tanpa meninggalkan kaidah atau aturan dalam menabuh gamelan. Gending soran berarti penyajian gendinggending dengan volume keras yang menekankan pada ricikan wingking (belakang) seperti demung, saron ricik, peking, bonang penembung, bonang barung, bonang penerus, kenong, dan gong. Adapun lirihan yaitu lirih atau lembut. Gending lirihan berarti penyajian gending-gending dengan volume lirih atau lembut yang menekankan pada ricikan garap ngajeng (depan) seperti gender barung, gender penerus, rebab, gambang, siter, suling, biasanya dibarengi garap vokal sindhenan dan gerongan, pada bentuk gending tertentu dalam bagian tertentu dengan senggakan, serta keplok yang sifatnya menyemarakkan lagu.

\section{Kendhangan Pamijen Gaya Yogyakarta}

Dalam seperangkat gamelan ageng gaya Yogyakarta, kendang dibedakan menjadi empat jenis berdasarkan bentuk dan ukurannya. Dari segi bentuk semuanya memiliki kemiripan atau kesamaan, tetapi ukuran masing-masing berbeda. Kendang yang paling besar disebut kendang ageng/ kendang bem/ kendang gending. Kendang yang memiliki ukuran sedang disebut kendang batangan, kendang gembyakan atau kendang ciblon. Kendang yang lebih kecil dari batangan disebut kendang dhundhung ketipung (penunthung), dan kendang yang paling kecil disebut kendang ketipung. Apabila dalam seperangkat gamelan ageng tidak memiliki dhundhung ketipung, maka perannya dapat digantikan dengan kendang ketipung yaitu sebagai dhundhungan dalam menyertai kendang ageng.

Kendhangan gaya Yogyakarta pada dasarnya dapat dibedakan menjadi tiga yaitu: (1) Kendhangan dengan kendang setunggal kendang ageng antara lain kendhangan Pengrawit, Mawur, Mawur Tungkakan, Semang, Jangga, Candra, Sarayuda, Raraciblon, Bandholan, Majemuk, Lahela, Ladrang, Ketawang; (2) Kendhangan dengan kendang kalih ( kendang ageng dan ketipung) antara lain kendhangan Gandrung-gandrung, Ladrang, Ladrang Gangsaran, Bimakurda, Sabrangan, Raja, Ketawang, Bubaran, Lancaran; dan (3) Kendhangan dengan kendang batangan atau gembyakan antara lain kendhangan kebar, ciblon, playon, srepeg, sampak, dan kendhangan yang mengikuti gerak baik tari ataupun wayang. Pada beberapa kendhangan yang menggunakan kendang ageng, kendang kalih dan kendang batangan, ada yang memiliki bentuk dan garap yang sifatnya umum dan ada yang khusus atau pamijen.

Kendhangan pamijen adalah kendhangan gawan gending, sehingga kendhangan ini merupakan kendhangan khusus untuk ngendhangi suatu gending bawaannya yang memiliki bentuk dan garap khusus. Kendhangan pamijen antara gending satu dengan yang lainnya memiliki bentuk dan garap yang berlainan, hal ini menjadi kekayaan bentuk dan garap serta merupakan ciri khas dari gending tertentu. Untuk memudahkan pemahaman dan penerapan kendhangan dalam suatu gending, maka dalam penulisan ini disertakan balungan gendingnya. Contoh: 
Bambang Tri Atmojo, Kendhangan Pamijen Gendhing Gaya Yogyakarta

1. Kendhangan Bandholan kendang setunggal kendang ageng untuk gending Caranggantung laras slendro patet manyura

Buka: $66156 i 6.66 i \quad 6533 \quad 5653 \quad 2126$

$$
\begin{aligned}
& . . . . . t, P, B .0^{\circ} . \\
& L_{\text {Lamba: }} 5 \cdot 3^{+} \cdot 6 \cdot 1 \cdot 3 \cdot 6^{+} \cdot 3 \cdot 2 \mathrm{kn}-\mathrm{I}
\end{aligned}
$$

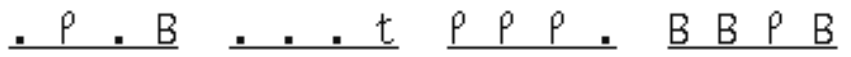

$$
\begin{aligned}
& .5 \cdot 3 \cdot 6 \cdot 123565352 \mathrm{kn}-\mathrm{II} \\
& . P B t . . \quad t \quad P P P . B B P B
\end{aligned}
$$

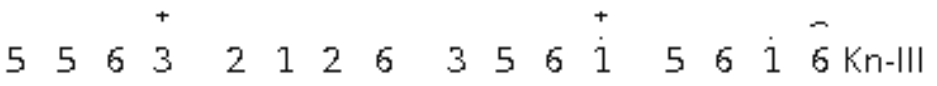

$$
\begin{aligned}
& . p \cdot B . \cdot \bar{t}^{p} p \rho p . \underline{B} \underline{p \rho \bar{t} p} \\
& \left.\begin{array}{llllllllllllllll}
3 & 5 & 6 & + & 6 & 5 & 2 & 3 & 5 & 6 & 5 & 3 & 2 & 1 & 2 & 6 \\
6
\end{array}\right) \mathrm{Kn}-\mathrm{IV}
\end{aligned}
$$

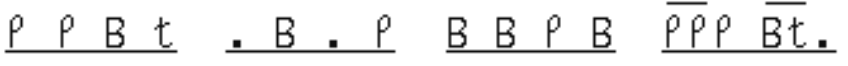

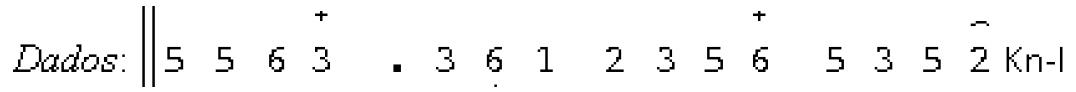

$$
\begin{aligned}
& . P . B . . \overline{t P} \rho P P . B B P B \\
& \begin{array}{llllllllllllllll}
5 & 5 & 6 & 3 & - & 3 & 6 & 1 & 2 & 3 & 5 & 6 & 5 & 3 & 5 & 2 \\
k n-11
\end{array} \\
& . P B t \underline{\rho} \cdot \bar{t} p \rho p . \quad B B P B \\
& \begin{array}{llllllllllllllll}
5 & 5 & 6 & 3 & 2 & 1 & 2 & 6 & 3 & 5 & 6 & 1 & 5 & 6 & 1 & 6 \\
6
\end{array}
\end{aligned}
$$

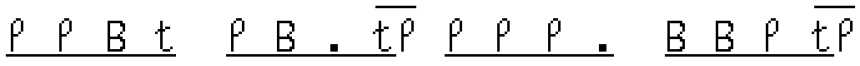

$$
\begin{aligned}
& \begin{array}{llllllllllllllll}
3 & 5 & 6 & 1 & 6 & 5 & 2 & 3 & 5 & 6 & 5 & 3 & 2 & 1 & 2 & 6 \\
6
\end{array} \text { kn- } v
\end{aligned}
$$

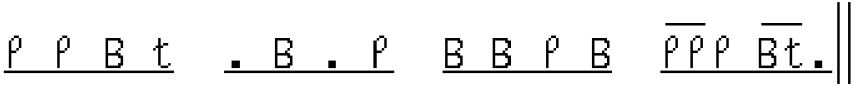


Wgelit (Kendhargan-nya sama dengan bagian Dadw)

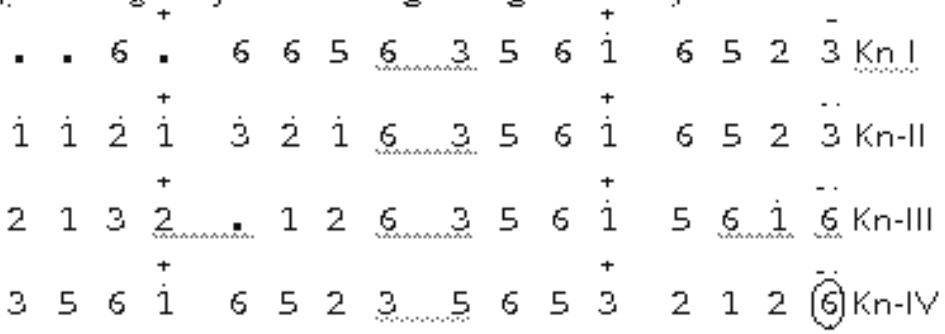

Pangkat dhowab:

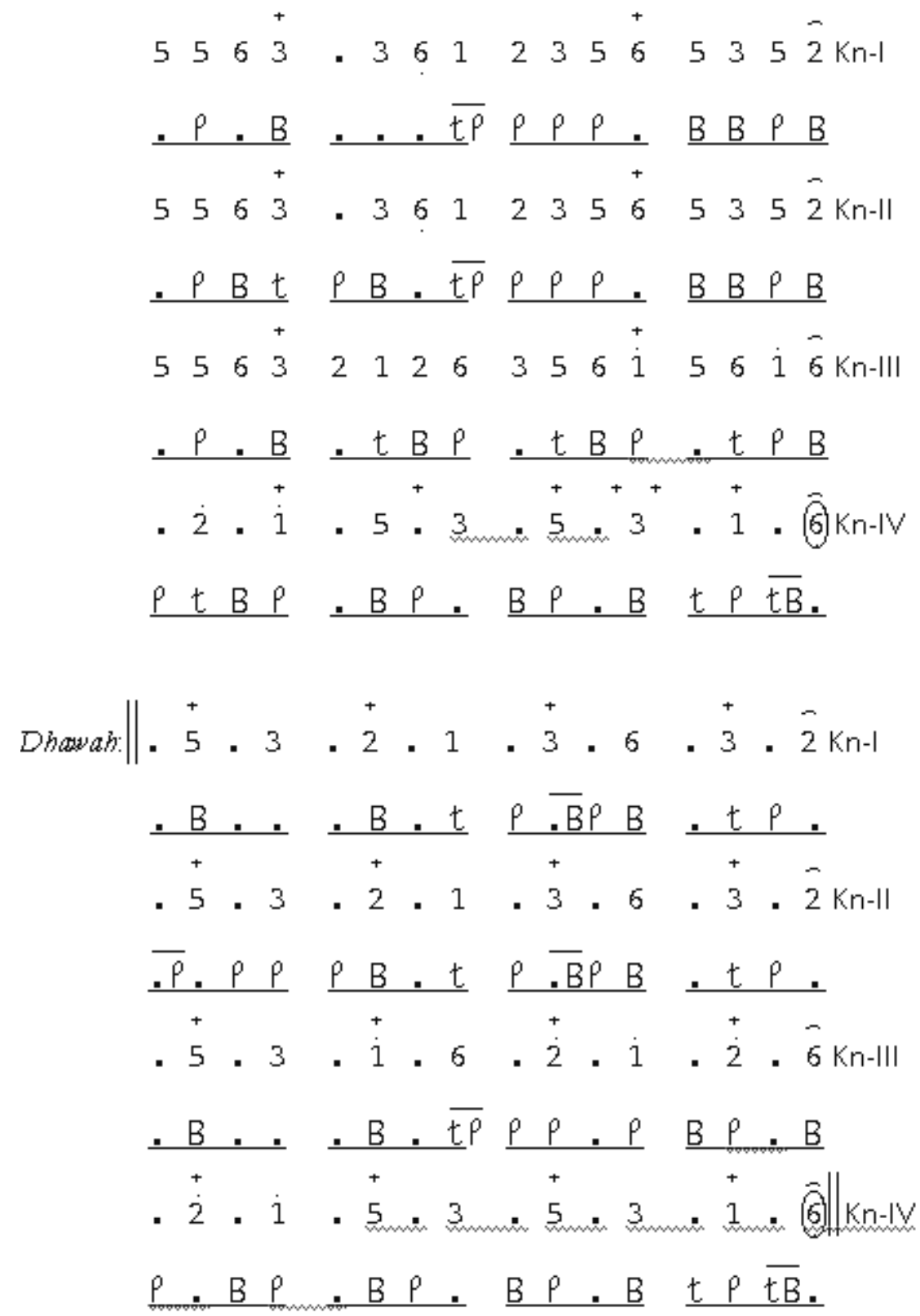




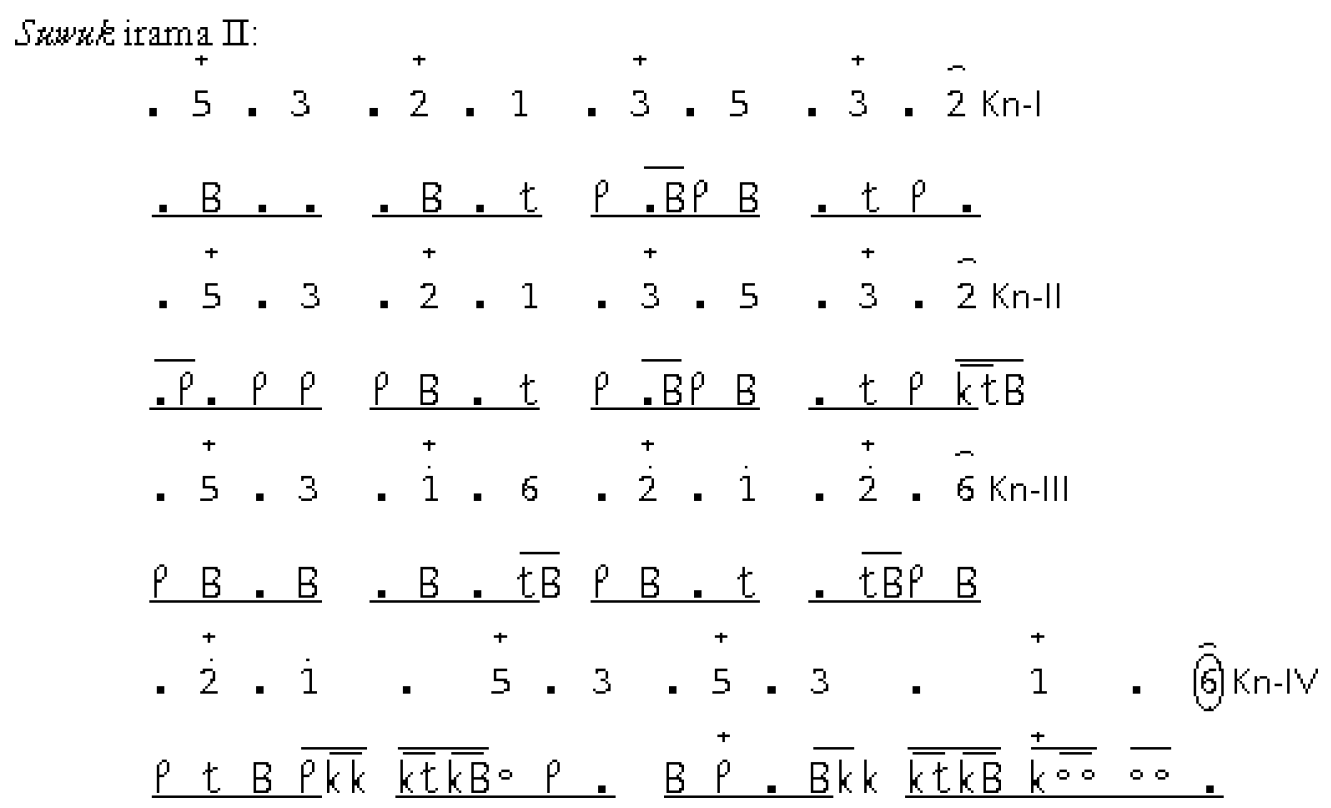

Bentuk kendhangan Bandholan sama dengan kendhangan Candra, tetapi memiliki sekaran yang berbeda. Kendhangan Candra dapat digunakan pada semua bentuk gending kethuk 2 kerep dhawah ketuk 4 laras slendro, sedangkan kendhangan Bandholan khusus digunakan untuk gending Caranggantung laras slendro patet manyura kethuk 2 kerep dhawah kethuk 4, biasanya disajikan

2. Kendhangan Majemuk Slendro kendang setunggal kendang ageng untuk gendinggending bentuk majemuk laras slendro.

Contoh: Gending Randhusekar laras slendro patet nem kethuk 2 kerep dhawah kethuk. 4 kendhangan Majemuk.

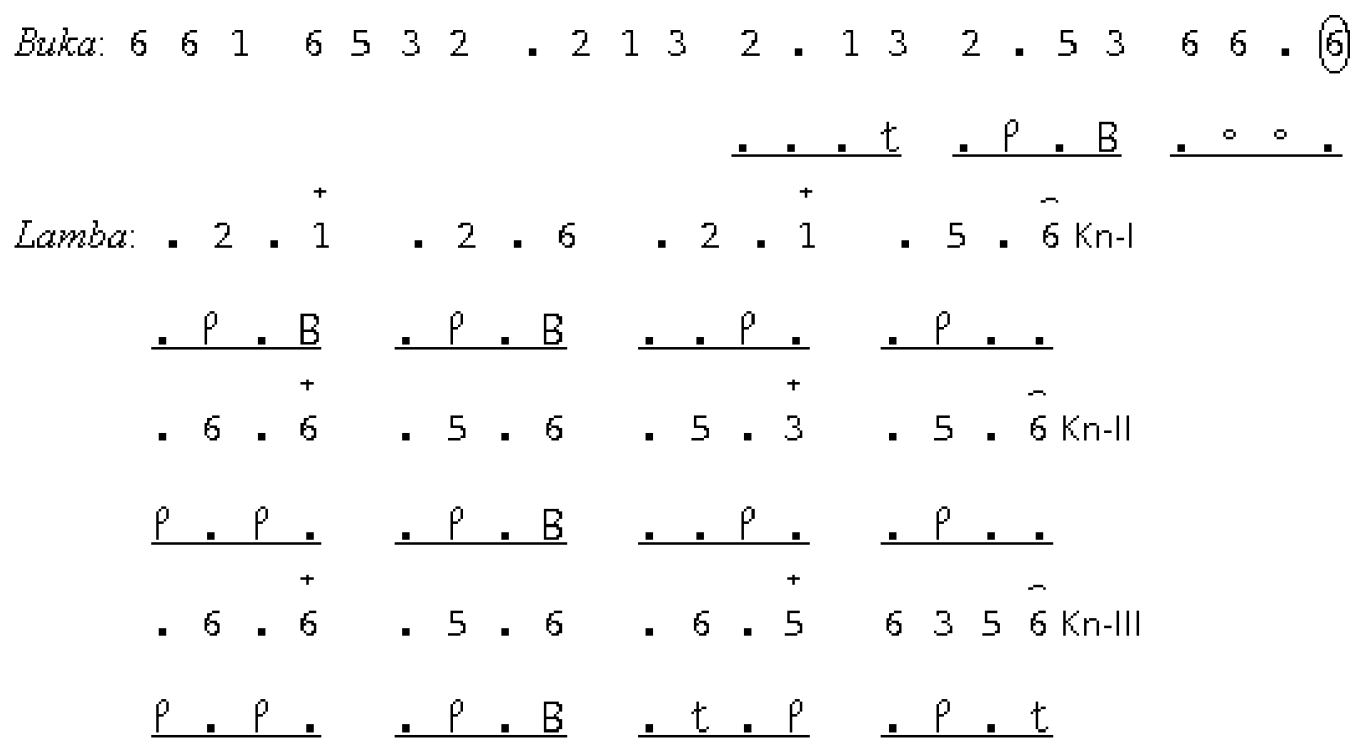

dengan garap lirihan. Pada bagian dados setiap satu kenongan terdiri dari 16 ketegan balungan, sehingga empat kenongan dalam satu gongan terdiri dari 64 ketegan balungan, demikian pula pada bagian dhawah yaitu setiap satu kenongan terdiri dari 16 ketegan balungan dan untuk empat kenongan dalam satu gongan terdiri dari 64 ketegan balungan. 
$33 .+3356 \quad 1 \quad 3 \quad 1 \quad 6 \quad 3532 \mathrm{kn}-\mathrm{V}$

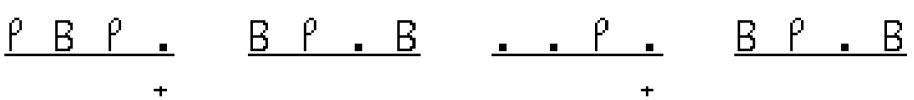

$\begin{array}{llllllllllllll}5 & 6 & 5 & 3 & 2 & 1 & 2 & 6 & 1 & 5 & 6 & 1 & \cdot 3 & 3\end{array} \mathrm{kn}-\mathrm{V}$

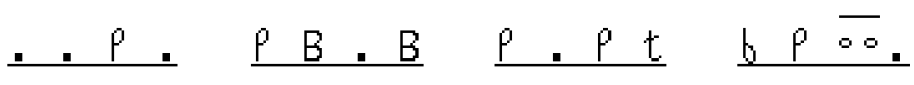
Dados:\|. $5 \cdot 3 \cdot 3 \cdot 2 \cdot 3 \cdot 6 \cdot 5 \cdot 3 \cdot 2 \mathrm{kn}-1$
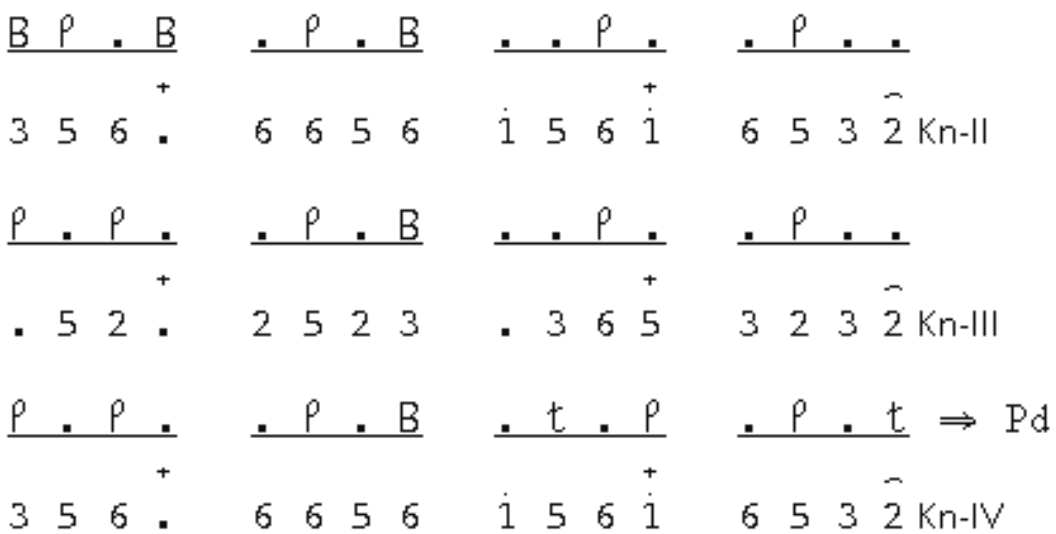

$\underline{P B}, \underline{B P} \cdot B, \cdot P \cdot B P \cdot B$

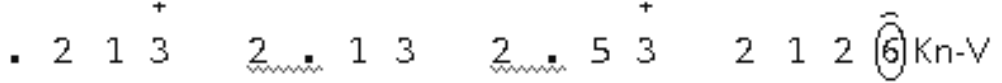

. $P . p B . B \quad p t \quad p \quad p \overline{0}$.

Kendhangan-nya sama dengan bagian dados.

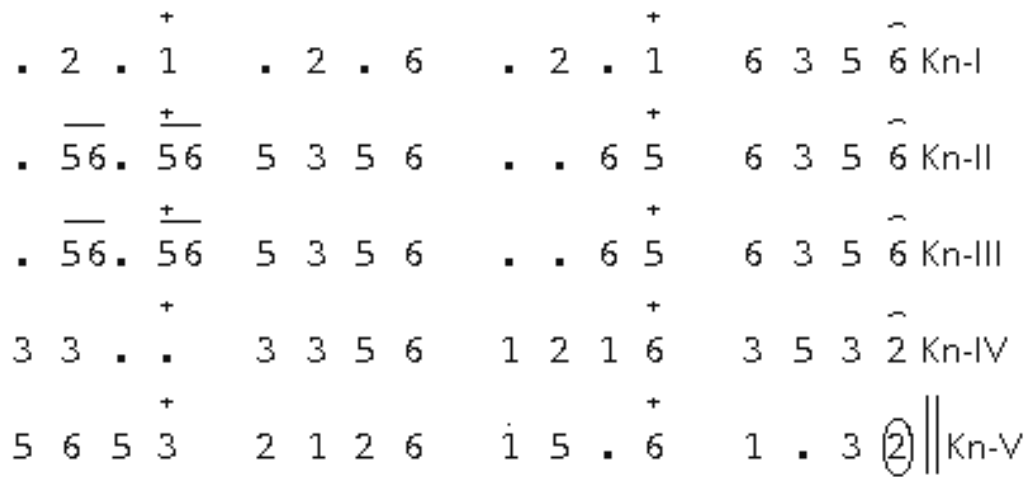

Pangkat dhawah:

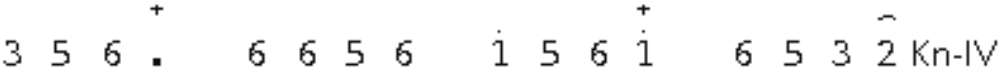

$$
\begin{aligned}
& \Rightarrow \frac{P B P \cdot}{+} \frac{B P \cdot B}{+} \frac{t \cdot P}{+++} \cdot \frac{t P B}{+} \\
& \cdot 5 \cdot 3 \cdot 2 \cdot 3 \cdot 5 \cdot 3 \cdot 1 \cdot 6 \mathrm{kn}-\mathrm{V} \\
& \underline{p t B P}, B P . \quad B P \cdot B, \bar{p} \cdot \overline{t B} .
\end{aligned}
$$




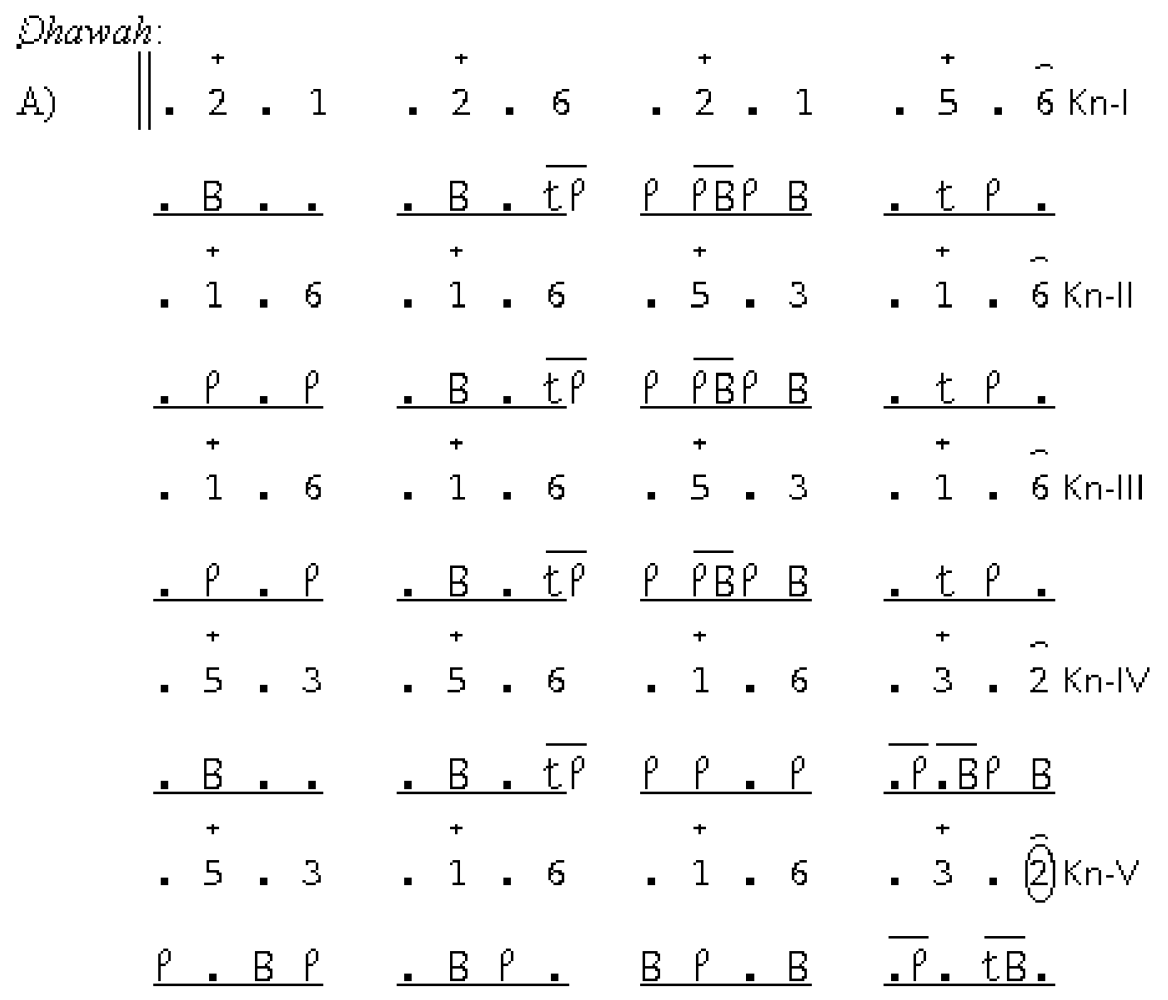

Untuk lagu bagian B kendhangan-nya sama dengan lagu bagian A.

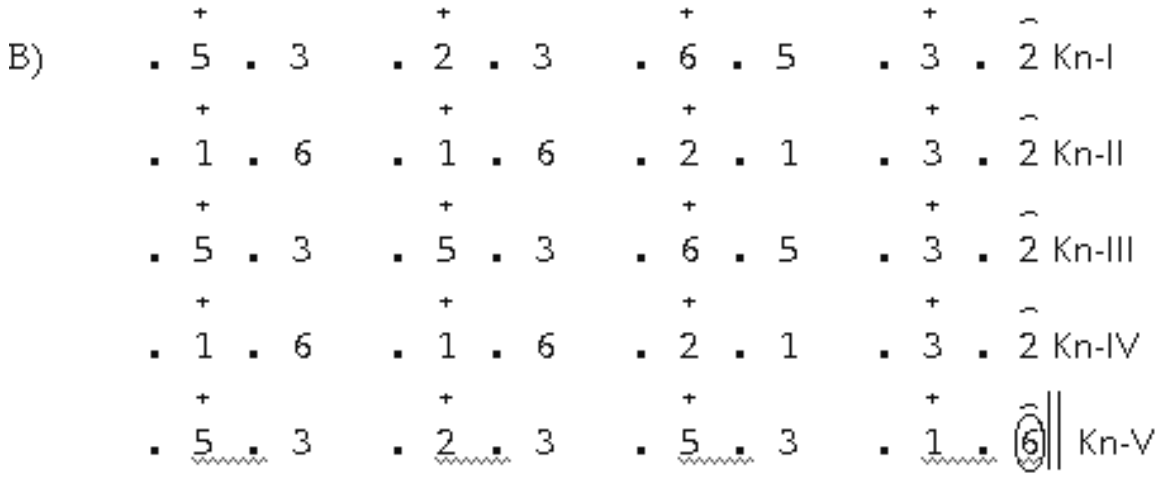

Seseran

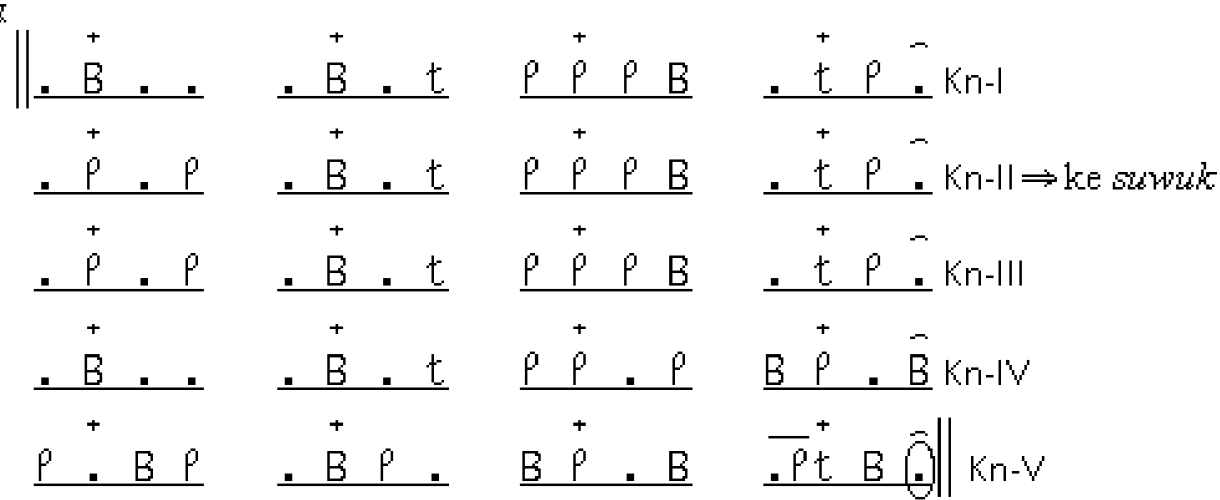


Sxwhe: (suwhe pada lagu bagian B yaitu seleb gong 6 )

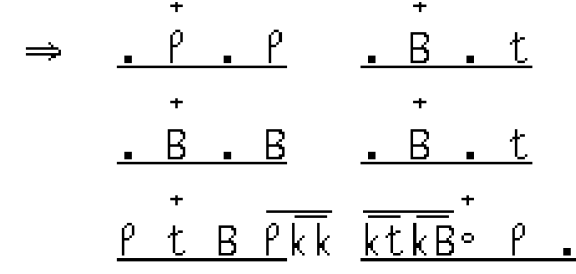

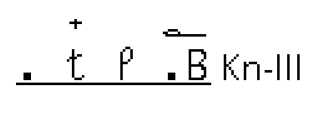

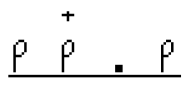

$\stackrel{+}{p} \cdot \overline{B \overline{k k}}$

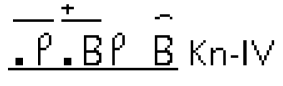

$\overline{\overline{k t} \overline{k B k}} \overline{+} \bar{~} \bar{c}$. kn-V
Kendhangan Majemuk slendro dapat digunakan pada gending-gending bentuk majemuk kethuk 2 kerep dhawah ketuk 4 laras slendro yang satu gongan terdiri dari lima kenongan. Pada bagian dados setiap satu kenongan terdiri dari 16 ketegan balungan, sehingga lima kenongan dalam satu gongan terdiri dari 80 ketegan balungan, demikian pula pada bagian dhawah yaitu setiap satu kenongan terdiri dari 16 ketegan balungan dan untuk lima kenongan dalam satu gongan terdiri dari 80 ketegan balungan.

Kendhangan Majemuk slendro tersebut di atas apabila diaplikasikan pada gending Majemuk laras slendro patet manyura pola penyajiannya dimulai dari buka, lamba, dados, pangkat dhawah, dhawah sesegan, dhawah ciblon dan suwuk. Untuk bagian dhawah ciblon irama III skemanya sebagai berikut:

Skema I

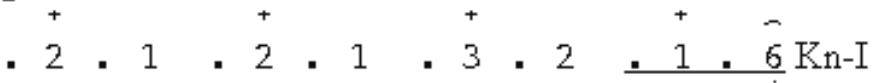

$$
\begin{aligned}
& \text {. B. . B. } \bar{t} \bar{\rho} \underline{\rho} \overline{\mathrm{B}} \rho \text { B } 1 / 2 \text { angkatan ciblon }
\end{aligned}
$$

Kendang ageng

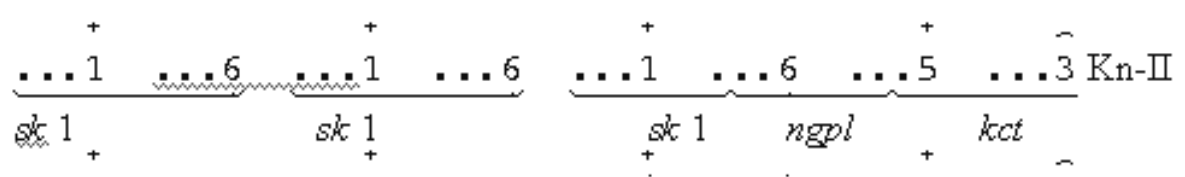

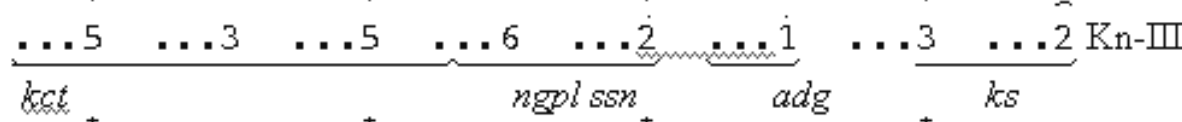

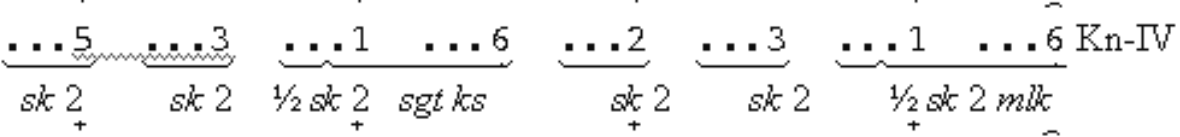

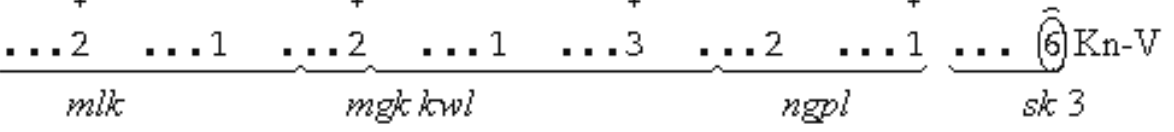

Skema II

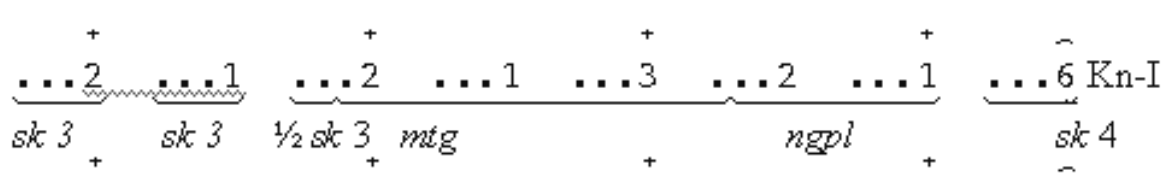

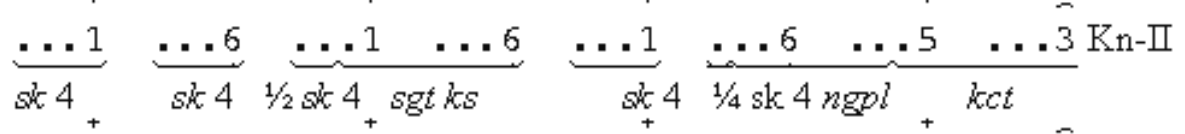

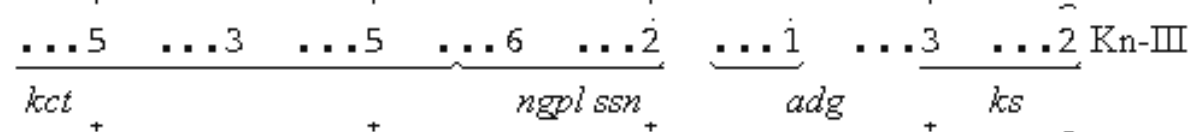

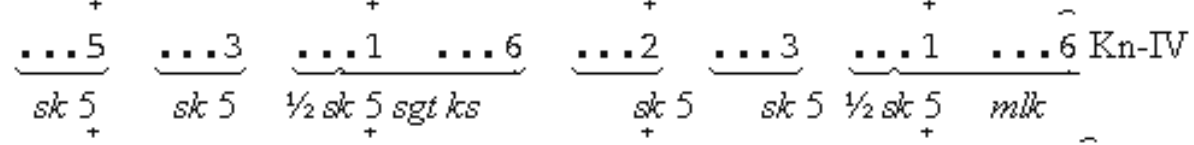

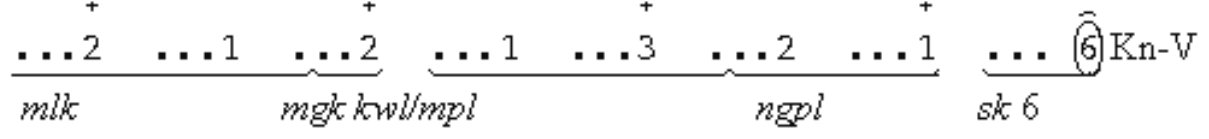


3. Kendhangan Ladrang Raraciblon

Kendang setunggal kendang ageng khusus untuk ladrang Jangkrik Genggong

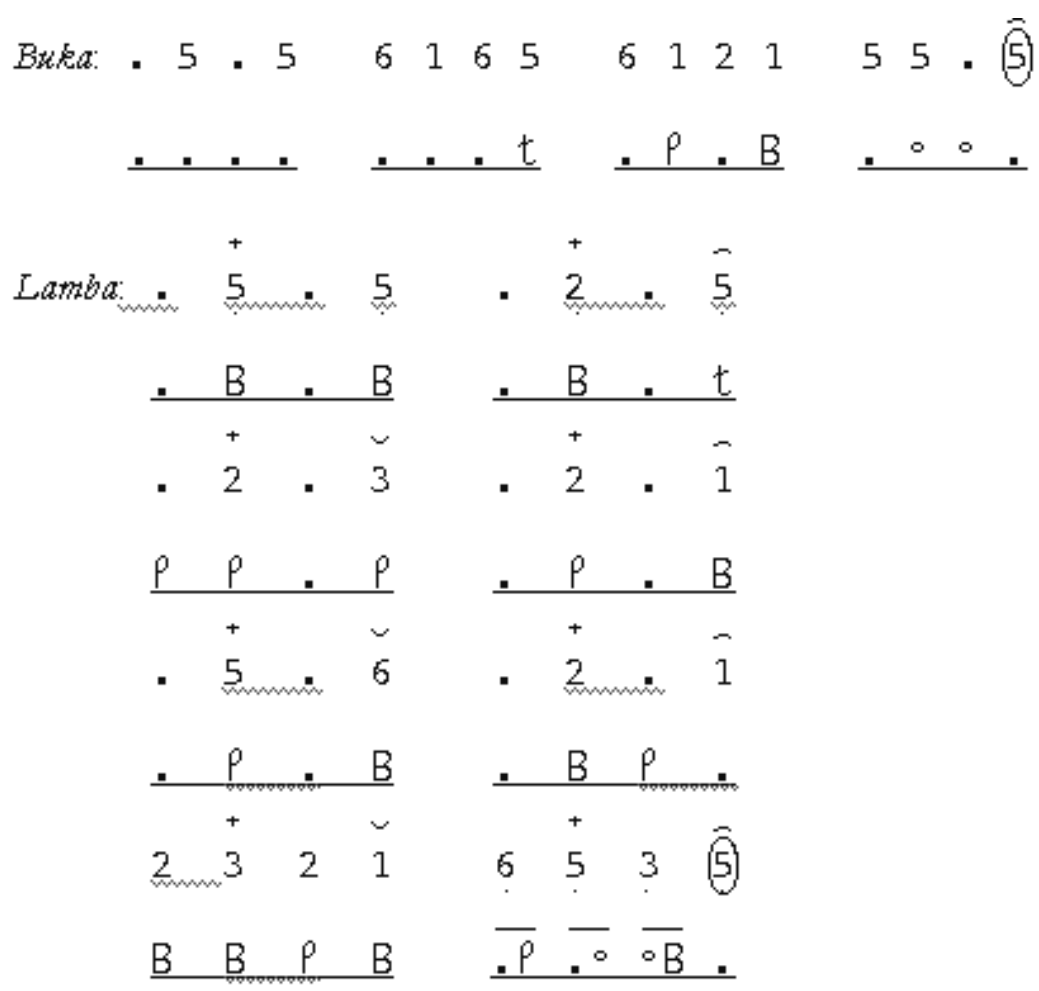

Dados irama I (hanya bagian umpak)

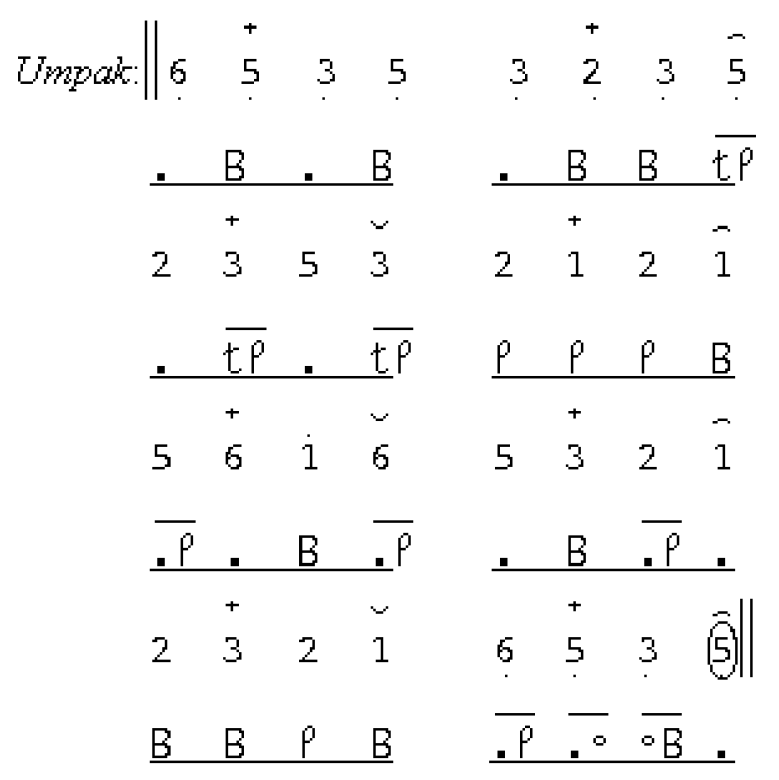

Dados irama II (bagian umpak dan ngelik)

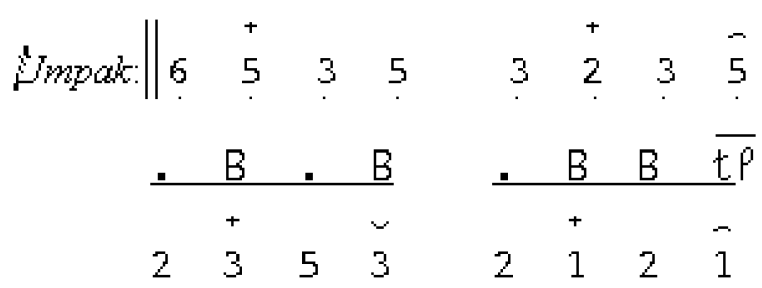




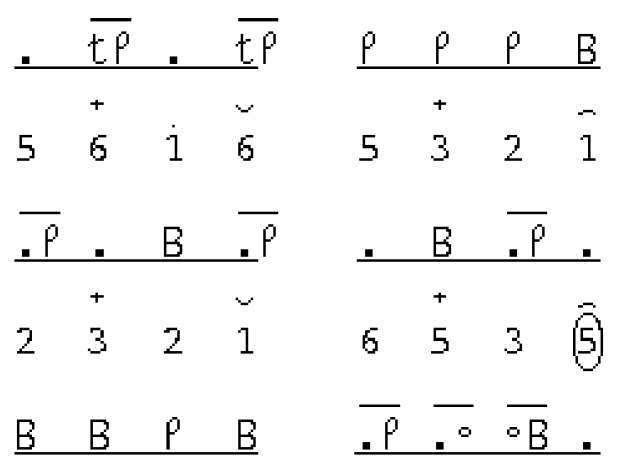

$\begin{array}{lllllllll}\text { Ngelik: } & 6 & 5 & 3 & 5 & 3 & 2 & 3 & 5\end{array}$
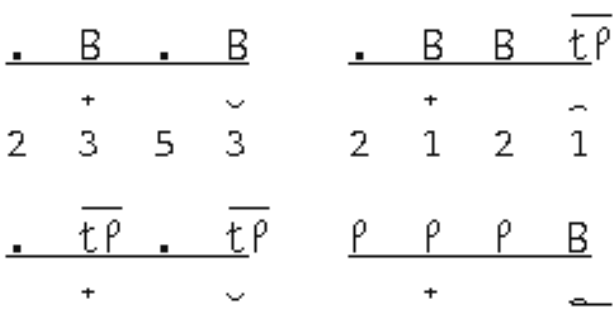

$\begin{array}{llllllll}5 & 6 & 3 & 5 & 1 & 2 & 1 & 61\end{array}$

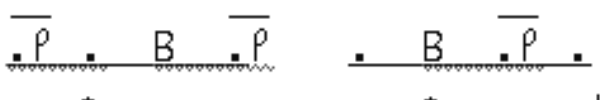

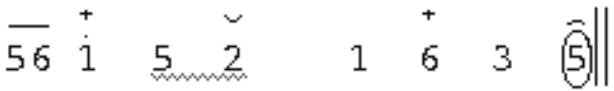

B B $P \quad B \quad \overline{. P} . \bar{\circ}$.

Suwuk gropak:

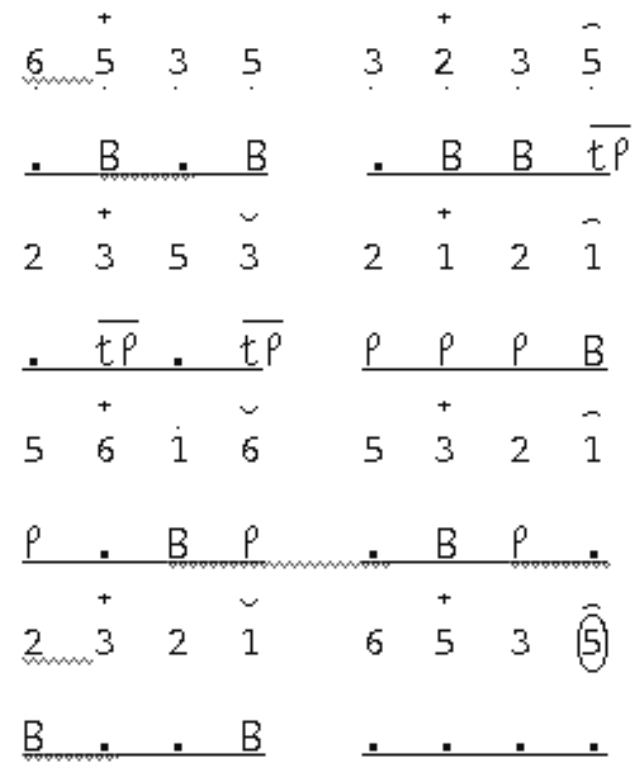


Ladrang Jangkrik Genggong laras slendro patet irama I dan irama II sama, pada bagian ngelik sanga kendhangan ladrang Raraciblon mempunyai menggunakan gerongan kinanthi jugag atau salisir, dua bagian lagu yaitu umpak dan ngelik. Dalam ladrang Jangkrik Genggong biasanya digunakan penyajian irama I hanya menggunakan bagian um- untuk iringan raksasa dalam adegan alas-alasan di pak, sedangkan dalam penyajian irama II meng- hutan.

gunakan bagian umpak dan ngelik. Kendhangan

4. Kendhangan Sabrangan kendang kalih khusus untuk gending-gending Gati

Contoh: Gati Langenbrangta lr. pl. pt. nem.

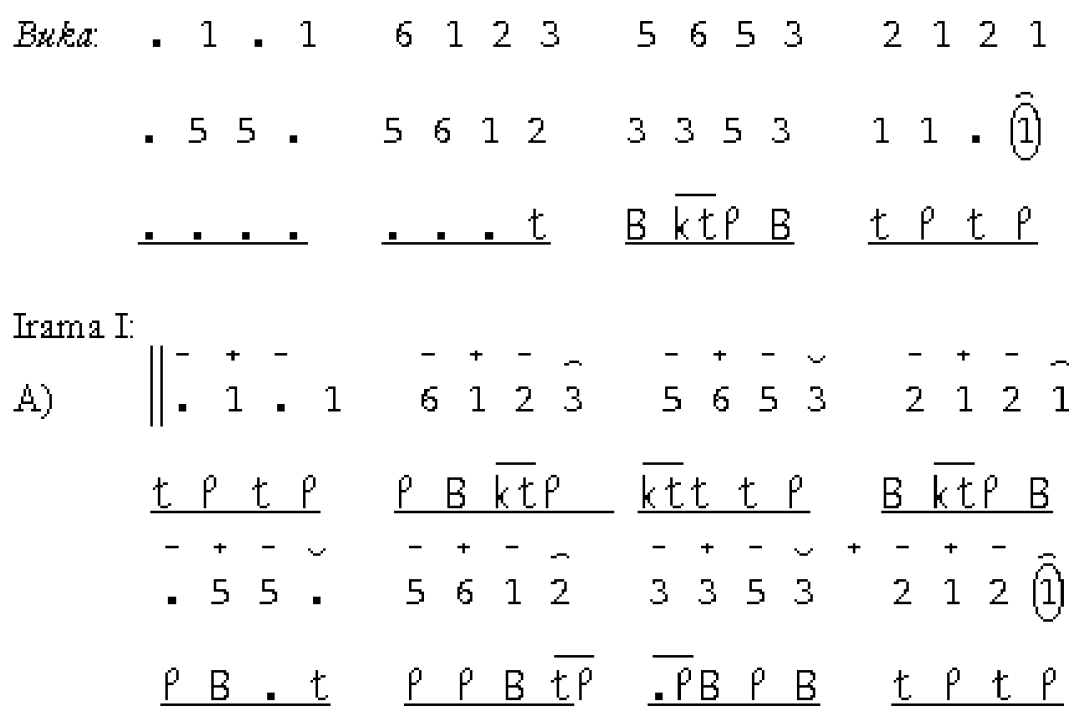

Kendhangan-nya sama dengan di atas:

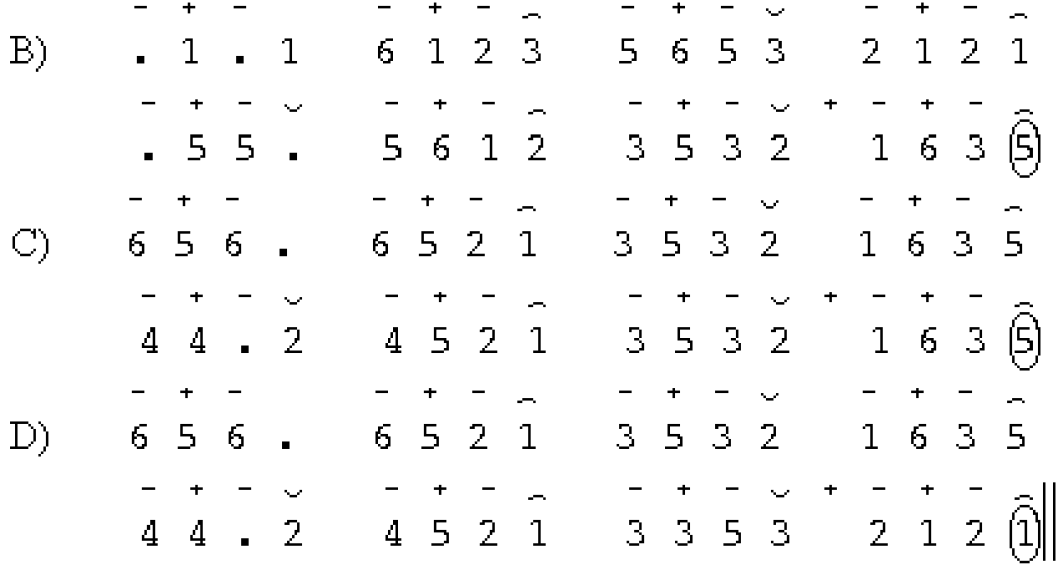

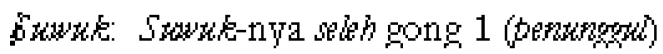

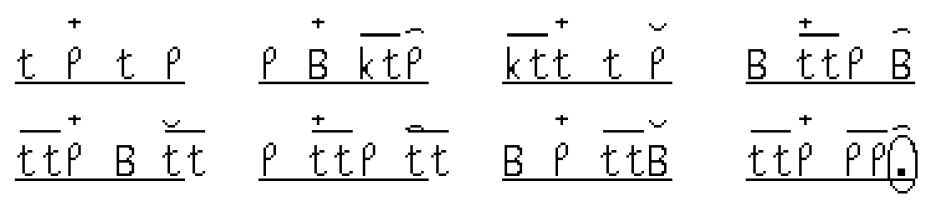


Kendhangan Sabrangan merupakan salah satu jenis kendhangan bentuk ladrang yang khusus digunakan pada gending-gending Mars atau Gati yang semuanya berlaras pelog, biasanya digunakan untuk iringan kapang-kapang maju dan mundur dalam tari bedhaya dan srimpi. Kendhangan Sabrangan hanya disajikan dalam irama I, pada penyajiannya disertai bedug, tambur dan trompet.

5. Kendhangan Ketawang kendang setunggal kendang ageng untuk gending Ranggajanur lampah Srimpen

Bxka: Coluk

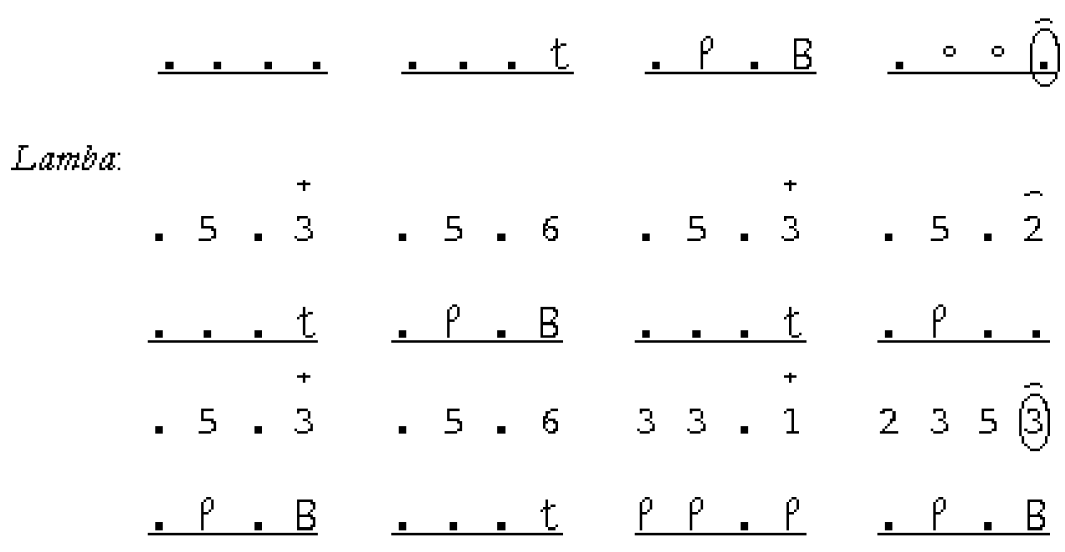

Dados:

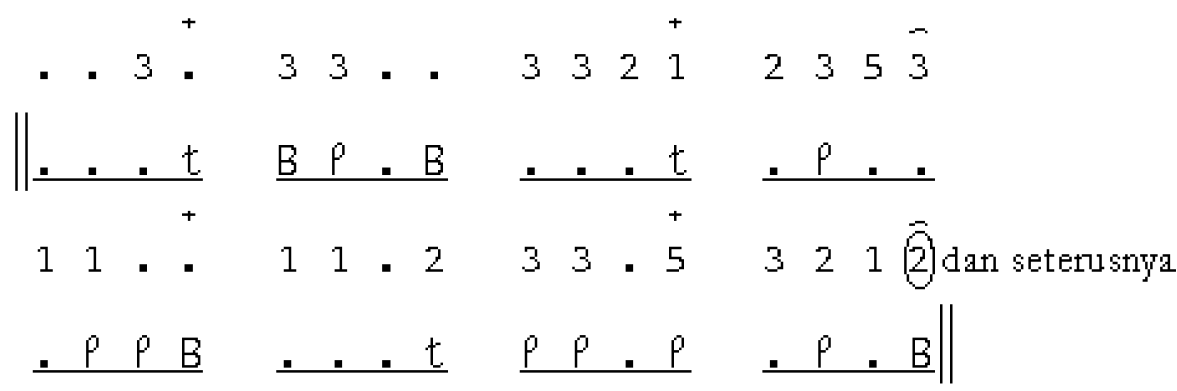

Kendhangan dados disajikan beberapa ulihan sesuai kebutuhan.

Pangkat dhawah: (Peralihan ke Ayak-ayak)

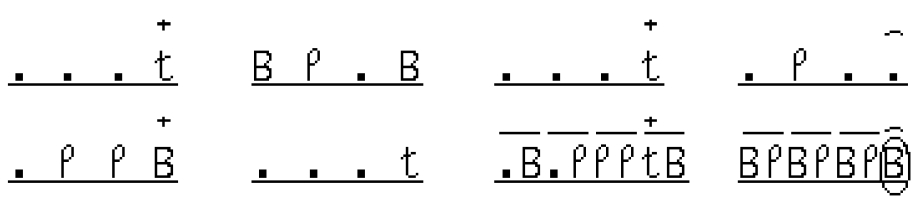

Kendhangan Ketawang kendang setunggal kendang ageng digunakan pada gending Ranggajanur untuk iringan srimpi Ranggajanur. Gending Ranggajanur memiliki bentuk lahela (ketawang gending), tetapi khusus untuk iringan srimpi Ranggajanur menggunakan kendhangan Ketawang kendang setunggal dan menggunakan tabuhan kemanak, maka dalam penyajiannya tidak menggunakan tabuhan kempul.

\section{Penutup}

Kendhangan pamijen gending gaya Yogyakarta pada dasarnya dapat dikelompokan menjadi tiga: (1) Kendhangan pamijen dalam bentuk gending ageng yaitu kendhangan Pengrawit, kendhangan Mawur Tungkakan Glendheng, kendhangan Mawur Tungkakan Wedhikengser, kendhangan Jangga Raraciblon, kendhangan Ganggong dan kendhangan Longkrang; (2) Kendhangan 
pamijen dalam bentuk gending tengahan yaitu kendhangan Candra Raraciblon, kendhangan Sarayuda Raraciblon, kendhangan Bandholan, kendhangan Majemuk, kendhangan Gandrunggandrung kendang kalih, kendhangan Lahela Gandrung-gandrung dan kendhangan Candra pada gending Karawitan iringan pakeliran; (3) Kendhangan pamijen dalam bentuk gending alit yaitu kendhangan Sabrangan, kendhangan Raja, kendhangan Ladrang Gangsaran, kendhangan Ladrang Bimakurda, kendhangan Ladrang Raraciblon, kendhangan Ladrang Bandholan, kendhangan Ladrang Karawitan kendang setunggal irama II, kendhangan Ladrang Karawitan kendang setunggal irama III, kendhangan Ladrang Karawitan kendang kalih irama III dan kendhangan Ketawang kendang setunggal.

Kendhangan pamijen ada yang menggunakan kendang setunggal kendang ageng, ada yang menggunakan kendang kalih dan ada yang dengan kendang batangan/ciblon. Pada penyajiannya ada yang bersifat mandiri yaitu dalam sajian uyon-uyon baik garap soran maupun garap lirihan, tetapi ada yang berfungsi sebagai iringan tari dan pakeliran.

Pola kendhangan pamijen ada dua macam yaitu bentuk gending umum antara lain kendhangan Ladrang Raraciblon, Cadra Raraciblon, Sarayuda Raraciblon, Gandrung-gandrung, Bandholan, Jangga Raraciblon, dan bentuk gending khusus seperti kendhangan Majemuk, Loro-loro, Ganggong dan Longkrang.

Kendhangan pamijen adalah kendhangan gawan gending, sehingga kendhangan ini merupakan kendhangan khusus untuk ngendhangi suatu gending bawaannya yang memiliki bentuk dan garap khusus. Kendhangan pamijen antara gending satu dengan yang lain ada yang sama bentuknya, tetapi berbeda sekaran-nya, bahkan ada yang berbeda bentuk dan sekaran-nya, perbedaan tersebut menjadi kekayaan bentuk dan garap serta merupakan ciri khas dari gending tertentu. Oleh karena itu kendhangan pamijen mutlak harus digunakan sesuai dengan gawan gendingnya.

\section{Kepustakaan}

Dewantara, K.H., 1967. Kebudayaan. Yogyakarta: Majelis Luhur Taman Siswa.

Jumaryanto, Ibnu, 2008. "Teknik Penyeteman Kendang Ki Margiyono Dalam Penyajian
Karawitan Iringan Pedalangan Gaya Yogyakarta”, Skripsi Program Studi S-1 Karawitan Jurusan Seni Karawitan Fakultas Seni Pertunjukan Institut Seni Indonesia Yogyakarta.

Karahinan, Wulan R.B., 1991. Gendhing-Gendhing Mataraman Gaya Yogyakarta dan Cara Menabuh Jilid I. Yogyakarta: K.H.P. Kridamardawa Karaton Ngayogyakarta Hadiningrat.

2001. Gendhing-Gendhing Mataraman Gaya Yogyakarta dan Cara Menabuh Jilid II. Yogyakarta: K.H.P. Kridamardawa Karaton Ngayogyakarta Hadiningrat.

Lindsay, Jennifer. 1991. Klasik Kitsch Kontemporer Sebuah Studi Tentang Seni Pertunjukan Jawa. Yogyakarta: Gajah Mada University Press.

Maleong, Lexy J., 1989. Metode Penelitian Kualitatif. Bandung: CV. Remaja Karya.

Martopangrawit, 1975. Pengetahuan Karawitan Jilid I. Surakarta: Akademi Seni Karawitan Indonesia Surakarta.

Poerwadarminta, W.J.S., 1939. Baoesastra Djawa, Batavia: J.B. Wolters Vitgevers Maatschappij N.V.

Pustokomardowo, R.B. 1953. Sastra Laras Dalam Karawitan. Yogyakarta: Proyek Javanologi Museum Sonobudoyo.

Siswanto. 1983. Pengetahuan Karawitan Daerah Yogyakarta. Jakarta: Direktorat Pendidikan Menengah Kejuruan Proyek Pengadaan Buku Menengah Kejuruan Departemen Pendidikan dan Kebudayaan.

Suhastjarja, R.M.A.P. 1985. Analisa Bentuk Karawitan. Yogyakarta: Akademi Seni Tari Indonesia.

Sukidjo, Sogi, 1976. Kendangan Gaya Yogyakarta. Surakarta: Akademi Seni Karawitan Indonesia.

Suwito. 2005. "Kendangan Batangan Di Yogyakarta: Kajian Teknik Permainan Ngiwo dan Nengen", Skripsi Program Studi S-1 Karawitan Jurusan Seni Karawitan, Fakultas Seni Pertunjukan, Institut Seni Indonesia Yogyakarta.

Trustho. 2005. Kendang Dalam Tradisi Tari Jawa. Surakarta: STSI Press. 